\title{
Menstrual Patterns of Progestin Injection Contraception and Combinations in Kisaran Barat District
}

\author{
Ira Puspita', Nur Afi Darti ${ }^{2}$ \\ ${ }^{1,2}$ Faculty of Nursing Universitas Sumatera Utara
}

\begin{abstract}
The increase in population and the high maternity death rate has caused the government to mitigate birth rate by providing KB (Family Planning), using contraceptive devices; one of them is progesterone and estrogen hormone injection, done by intramuscularly method in fertility-aged women. Its side-effect isthat it can influence menstruation irregularity. The objective of the research was to find out menstruation pattern of the users of progestin and combination injections at Kelurahan Sendang Sari and Kelurahan Dadi Mulyo, Kisaran Barat Sub-district, where the research was done. The population was 348 people at the two villages, and 76 of them were used as the samples, taken by using accidental sampling technique. The result of the research showed that 32 respondents $(84.2 \%)$ were not in abnormal category in their menstruation pattern, using progestin injection, and 29 respondents $(76.3 \%)$ were in abnormal category in the menstruation pattern, using combination injection. It is recommended that $\mathrm{KB}$ counselors provide counseling about the mechanism of the work of injection contraception which causes side-effect of menstruation irregularity.
\end{abstract}

Keyword: Injection Contraceptive, Menstruation Pattern .

Received 04 February 2019 | Revised 14 May 2019| Accepted 26 January 2019

\section{Introduction}

Indonesia is a developing country with an increasing number of population growth as well as high maternal mortality and reproductive health needs. The Indonesian government through the National Population and Family Planning Agency (BKKBN) will emphasize the number of child births, welfare of mothers and children, distance and ideal age for childbirth, regulate pregnancy in the management of family planning programs by using contraception to create a healthy family and quality (RI Ministry of Health, 2014).

*Corresponding author at: Jl. Prof.Maas No. 03 Kampus USU, Medan, Indonesia 
Injectable contraception is a hormonal contraception that is intramuscularly injected as an effort to prevent pregnancy in the form of the hormone progesterone and estrogen in women of childbearing age. The use of injectable contraception affects the hypothalamus and pituitary. There are 2 types of injection contraception that are now widely used, namely combination injections (1 month) and progestin injections (3 months) (Mulyani, 2013: 87).

Combination injections (I months) contain $25 \mathrm{mg}$ of Depo Medroxyprogesterone Acetate and Estradiol $5 \mathrm{mg}$. 1-month injection contraception is very effective during the first year of use but has a disadvantage of changing menstrual patterns such as irregular, spotting or bulging bleeding, intermittent bleeding for up to ten days. Then, progestin injection contraception (3 months) is a contraceptive method that is given intramuscularly every three months. This type of contraception is DMPA (Depot medroxy progestin acetate) which is given in a dose of 150 $\mathrm{ml} / \mathrm{gr}$ intramuscularly. Effective injection of progestin is very high, but the injection is carried out regularly in accordance with the schedule specified. However, the disadvantages are menstrual disorders such as amenorrhea, spooting, metroragia, menoragia (Mulyani, 2013: 94).

The mechanism of injection contraception works is inhibiting ovulation by suppressing the expenditure of follicle stimulating hormone (FSH) and Luteneizing hormone ( $\mathrm{LH})$, thickening the cervical mucus so that it inhibits sperm penetration through the uterine cervix, inhibits implantation of the ovum in the endometrium (Pinem, 2009).

Injectable contraception is a hormonal contraception that is intramuscularly injected as an effort to prevent pregnancy in the form of the hormone progesterone and estrogen in women of childbearing age. The use of injectable contraception affects the hypothalamus and pituitary. (Mulyani, 2013: 87).

The types of injection contraception, namely progestin injections, are contraceptive methods that are given intramuscularly every three months. The working mechanism of a progestin injection contraception is to prevent ovulation by thickening cervical mucus to prevent sperm from titrating or preventing the implantation of fertilized eggs (IFPA, 2008). Lack of contraception is a menstrual disorder such as a normal menstrual pattern that becomes abnormal which changes to amenorrhea, which is not menstruating every month for 3 consecutive months. Spoting, which is bleeding spots outside of menstruation, metroragia, which is excessive bleeding outside the menstrual period, menoragia, namely excessive menstruation, weight gain, dizziness and headaches, pimples on the body or face can be accompanied by infection if longterm use, increases risk esteoporosis (Melani, 2010).

Combination contraception is a method that is given every month by intramuscular injection containing $25 \mathrm{mg}$ of Depo Medroxyprogesterone Acetate and 5 grams of Estradiol Sipionate. The mechanism of action of contraception in the mechanism of action between combined injection contraception with the same oral ie preventing ovulation causes suppression of secretion of follicle stimulating hormone (FSH) by increasing Lutenizing Hormone (LH) 
(WHO, 2004). Losses Combination contraception (1 month), namely (1) changes in menstrual patterns such as irregular, spot or spoting bleeding, intermittent bleeding for up to ten days;

Menstruation is periodic bleeding from the uterus which starts around 14 days after ovulation periodically due to the release of uterine endometrial relaxation (Bobak, 2004). According to Pritchard (1991), regular menstrual patterns include menstrual cycles that vary from 28 days to 30 days, the duration of bleeding between 4-6 days but 2-8 days is still considered physiological, menstrual blood counts of 25-60 ml. As for Monawa et al (2016), namely the average menstrual cycle is 28 days and the cycle can range from 21-35 days in adults.

According to Kusmiran (2011), the factors that influence irregular menstruation:

(1) Hormone factors that affect menstruation in a woman, Follicle Stimulant Hormone (FSH) released by the pituitary, estrogen produced by the ovary, Luteinizing Hormone (LH) produced by the pituitary, as well as progesterone produced by the ovary.

(2) Enzyme Factors Hydrolysis contained in the endometrium damages cells that play a role in protein synthesis, which disrupts metabolism resulting in endometrial regression and bleeding.

(3) The vesicular factor in the proliferation phase is the formation of a vascular system in the functional layer of the endometrium. The growth of the endometrium also follows arteries, veins, and the relationship between the two with endometrial regulation, arises statically in venena and the channels that connect with the arteries, and finally ovulation and bleeding with hermatoma formation, both from arteries and veins .

(4) Prostaglandin factors, namely (endometrium containing prostagladin E2 and F3 in the presence of endometrial disintegration, prostagladin is released and causes contraction of the myometrium as a factor to limit menstrual bleeding.

(5) Body weight affects menstrual function. According to Rejeki (2014), nutritional status can have an influence on menstrual patterns where obesity is also accompanied by anovulatory cycles due to an increase in tonic estrogen levels which can cause disruption of irregular menstrual cycles. Body Mass Index (BMI) or Body Mass Index (BMI) is a simple tool or way to monitor the nutritional status of adults, especially those associated with underweight and overweight.

(6) Physical activity, which is a moderate and severe level of activity can limit menstrual function. Heavy physical activity stimulates the inhibition of Gonadotropin Releasing Hormone (GNRH) and Gonotropin activity thereby reducing levels of serum estrogen.

(7) Stress causes systemic changes in the body, especially the nervous system in the hypothalamus through changes in prolactin or endogenous opiate which can affect basal cortisol elevation and reduce the hormone Lutein Hormone ( $\mathrm{LH})$ which causes amenorrhea. 
(8) The use of injectable contraception for more than 1 year is in accordance with the purpose of contraception, which is to space pregnancy and one of the advantages of DMPA injection contraception method is to prevent long-term pregnancy. DMPA injection contraceptive method, women can adjust the distance of pregnancy as desired with the duration of DMPA injection contraceptive use. the duration of use of DMPA injection contraception for $\leq 1$ year and more than 1 year there is a menstrual disorder that is mostly amenorrhoea (Munayarokh, 2014).

\section{Research Methods}

The design used in this study is descriptive which aims to determine the menstrual pattern in users of progestin and combination injection contraception in the western range sub-district, precisely in the Sendang Sari and Dadimulyo Sub-Districts totaling 348 people with a total sample of 76 people, data collection techniques used are accidental techniques sampling.

\section{Research Result}

Table 1. Frequency distribution and percentage of menstrual patterns of progestin and combination injectable contraceptive users

\begin{tabular}{lllll}
\hline $\begin{array}{l}\text { Menstrual } \\
\text { Pattern }\end{array}$ & $\begin{array}{l}\text { Progestin } \\
\text { Injection } \\
\text { Contraceptive }\end{array}$ & \multicolumn{3}{c}{$\begin{array}{l}\text { Combination } \\
\text { Injection } \\
\text { Contraceptive }\end{array}$} \\
\hline & f & $\%$ & f & $\%$ \\
\hline Normal & 6 & 15,8 & 9 & 23,7 \\
Abnormal & 32 & 84,2 & 29 & 76,3 \\
\hline
\end{tabular}

Table 2. Frequency and Percentage of Menstrual Cycle Distribution of Progestin and Combination Injections Users

\begin{tabular}{|c|c|c|c|c|c|}
\hline \multirow[t]{2}{*}{ Menstrual Cycle } & \multicolumn{2}{|c|}{$\begin{array}{l}\text { Progestin } \\
\text { Injection } \\
\text { Contraceptive }\end{array}$} & \multicolumn{3}{|c|}{$\begin{array}{l}\text { Combination } \\
\text { Injection } \\
\text { Contraceptive }\end{array}$} \\
\hline & $f$ & $\%$ & $\mathrm{f}$ & & $\%$ \\
\hline Normal (21-35) & 15 & 39,5 & 20 & & 52,6 \\
\hline $\begin{array}{l}\text { Tidak normal } \\
\geq(21-35)\end{array}$ & 23 & 60,5 & 18 & 47,4 & \\
\hline
\end{tabular}

Table 3. Frequency Distribution and Long Menstrual Percentage of Progestin Injections and Combination Users

\begin{tabular}{lllll}
\hline $\begin{array}{l}\text { Menstrual } \\
\text { Period }\end{array}$ & $\begin{array}{l}\text { Progestin } \\
\text { Injection } \\
\text { Contraceptive }\end{array}$ & & $\begin{array}{l}\text { Combination } \\
\text { Injection } \\
\text { Contraceptive }\end{array}$ & \\
\hline & $\mathrm{f}$ & $\%$ & $\mathrm{f}$ & $\%$ \\
\hline Normal (2-8) & 16 & 42,1 & 23 & 60,5
\end{tabular}



Abnormal
22
$57,9 \quad 15$
39,5

$\geq(2-8)$

Table 4. Frequency Distribution and Percentage of Menstrual Blood Counts in Progestin and Combination Injections

\begin{tabular}{lllll}
\hline $\begin{array}{l}\text { Amount of } \\
\text { Menstrual Blood }\end{array}$ & $\begin{array}{l}\text { Progestin } \\
\text { Injection } \\
\text { Contraceptive }\end{array}$ & & \multicolumn{2}{l}{$\begin{array}{l}\text { Combination } \\
\text { Injection } \\
\text { Contraceptive }\end{array}$} \\
\hline & $\mathrm{f}$ & $\%$ & $\mathrm{f}$ & $\%$ \\
\hline $\begin{array}{l}\text { Normal } \\
(30-80 \mathrm{ml})\end{array}$ & 13 & 34,2 & 9 & 23,7 \\
$\begin{array}{l}\text { Abnormal } \\
\geq(30-80 \mathrm{ml})\end{array}$ & 29 & 65,8 & 25 & 76,3 \\
\hline
\end{tabular}

Table 5. Distribution of Frequency and Percentage of Dysmenorrhoea Contraceptive Users in Progestin and Combination

\begin{tabular}{lllll}
\hline Menstrual Pain & $\begin{array}{l}\text { Progestin } \\
\text { Injection } \\
\text { Contraceptive }\end{array}$ & \multicolumn{3}{c}{$\begin{array}{l}\text { Combination } \\
\text { Injection } \\
\text { Contraceptive }\end{array}$} \\
\hline & $\mathrm{f}$ & $\%$ & $\mathrm{f}$ & $\%$ \\
\hline Yes & 3 & 7,9 & 9 & 23,7 \\
Not & 35 & 92,1 & 29 & 76,3 \\
\hline
\end{tabular}

Then the results of the study on the duration of menstrual pain that was felt in the most progestin injection contraceptive users were 0 days, which did not reduce menstrual pain by 35 people $(92.1 \%)$ and the lowest 2 days ie 1 person $(2.6 \%)$ while the results of the study regarding the longest period of menstrual pain that was felt by the users of combined injection contraception was 0 days, that is, there was no menstrual pain as many as 29 people $(76.3 \%)$ and duration of menstrual pain $1,2,3$, days which was 9 people $(23,7 \%)($ mean $=0.11, \mathrm{SD}=$ $0.388)$.

Table 6. Frequency Distribution and Long Percentage of Menstrual Pain Contraception Injection Progestin and Combination Users

\begin{tabular}{lllll}
\hline $\begin{array}{l}\text { Lama } \\
\text { Haid }\end{array}$ & Nyeri & $\begin{array}{l}\text { KB } \\
\text { Suntikan } \\
\text { Progestin }\end{array}$ & \multicolumn{3}{l}{$\begin{array}{l}\text { KB } \\
\text { Suntikan } \\
\text { Kombinasi }\end{array}$} \\
\hline & f & $\%$ & f & $\%$ \\
\hline 0 hari & 35 & 92,1 & 29 & 76,3 \\
1 hari & 2 & 5,3 & 3 & 7,9 \\
2 hari & 1 & 2,6 & 3 & 7,9 \\
3 hari & - & - & 3 & 7,9 \\
\hline
\end{tabular}




\section{Research Discussion}

\subsection{Menstrual Patterns of Progestin and Combination Contraceptive Users}

The results of the study found 32 progestin injection contraception users (84.2\%) experienced abnormal menstrual patterns while in combination injection injection users there were 29 people (76.3\%) who experienced abnormal menstrual patterns. Menstrual patterns are menstrual cycle regularity, duration of menstruation or the length of menstruation and the amount of menstrual blood (Manuaba, 2007). Side effects that can be obtained from the use of contraceptives can affect menstrual patterns or menstruation so that sometimes someone is very considerate in using contraception. Disadvantages of using progestin and combination contraceptives are changes in menstrual patterns such as irregular, spotting or spooting bleeding, intermittent bleeding for up to ten days. (Mulyani, 2013). The mechanism of action for hormonal progestin injection contraception by suppressing the ovulation phase of a person, the ovulation phase is good depending on the level of estrogen in the circulation. When injecting progestin levels in the circulation it increases to suppress feedback from hypothalamic gonadotropin releasing factors. Then it will prevent pituitary secretion by inhibiting the surge of luteinizing hormone ( $\mathrm{LH})$ with the main task of blocking the ovulation phase (egg maturation). In normal circumstances, LH surge is the most important indicator of ovulation. LH surge causes rupture of the foliker. This ovulation disorder is due to the absence of gonadotropin / low, so that there is no stimulus to the ovary, no folliculogenesis, no secretion of estrogen, hypogonotdropin. Hipesterogen will provide clinical symptoms of amenorrhea or irregular menstrual disorders due to the absence of endometrial growth (Wirakusumah.F.et.al, 2010). While the use of combined hormonal injection contraception works through inhibition of feedback on the hypothalamus to suppress GnRH and plasma gonadotropin secretion, thus blocking ovulation by suppressing FSH secretion so as to suppress the release of estrogen which causes the maturation of follicles not optimal and the presence of progesterone which can suppress LH work to inhibit release of secondary oocytes from follicles which will inhibit a person's ovulation phase. But sometimes the use of combined injection contraception causes a person's normal menstrual pattern caused by a person's body reaction and hormonal mechanisms in a person's body (Hardisman, 2014).

\subsection{Menstrual Cycle Injecting Progestin and Combination Users}

Based on the results of research on menstrual cycles in progestin injectable contraceptive users there were abnormal $\geq 21-35$ days as many as 23 people $(60.5 \%)$ while combination injection users had normal 21-35 days as many as 20 people 
$(52.6 \%)$. Things that can be found in using progestin injection contraception are the presence of a menstrual cycle that is elongated or shortened. Side effects on progestin contraceptive use are very high due to the content found in progestin injection contraceptives, namely the hormone progesterone (Mulyani, 2013). In the use of hormonal progestin injection contraception there is a mechanism of action by suppressing the ovulation phase of a person, the ovulation phase is good depending on the level of estrogen in the circulation. The mechanism of action is to suppress the feedback work of hypothalamic gonadotropin releasing factors. Then it will prevent pituitary secretion by inhibiting the surge of luteinizing hormone (LH) with the main task of blocking the ovulation phase (egg maturation). Normally the LH surge is an important indicator in the occurrence of ovulation which causes the primary follicle to develop in the ovary which will become the follicle deaf, if the LH and FSH are pressed the working fusion is suppressed so that de graaf follicles do not ripen, so that endometrial growth is imperfect and affects and blocks someone's ovulation (Sukarni, 2013).

In combination contraceptive use is relatively normal and abnormal, this is caused by the presence of a combination of injectable contraceptives, namely the hormone estrogen and progesterone. Combined hormonal injection contraception works through inhibition of feedback on the hypothalamus to suppress GnRH and plasma gonadotropin secretion, thereby blocking ovulation by suppressing FSH secretion so that it suppresses estrogen release which causes non-optimal follicle maturation and progesterone content which can suppress LH work to inhibit oocyte release secondary to the follicle which will inhibit one's ovulation phase. This event will cause irregularity in one's menstrual cycle. A normal and regular menstrual cycle is characterized by ovulation. Then in the post ovulation period (secretion) the maturation of follicles that are not optimal will become the corpus luteum. The corpus luteum secretes the hormone progesterone and the hormone estrogen that is not optimal. In the use of combination endometrial injections of hormonal injections will be atrophy which will interfere with implantation, causing endometrium to stop the production of the hormone estrogen and progesterone. This condition will cause irregular menstruation (Purwoastuti et al, 2015).

\subsection{Duration of Menstrual Progestin Injections and Combination Users}

In the results of this study it was found that the majority of prolonged abnormal progestin injection contraceptives $\leq 2-8$ days were 22 people $(57.9 \%)$ whereas 23 to 8 
$(60.5 \%)$ were used for normal combination injection contraception users. In the use of progestin injection contraception has a long side effect of a person's menstruation can be elongated or shortened (Pinem, 2009). Basically a normal menstrual cycle will follow the number of bleeding days or normal menstrual periods with a range of 2-8 days. In the use of hormonal progestin injection contraception there is a mechanism of action by suppressing the ovulation phase of a person, the ovulation phase is good depending on the level of estrogen in the circulation. The mechanism of action is to suppress the feedback work of hypothalamic gonadotropin releasing factors. Then it will prevent pituitary secretion by inhibiting the surge of luteinizing hormone (LH) with the main task of blocking the ovulation phase (egg maturation). Normally the LH surge is an important indicator in the occurrence of ovulation which causes the primary follicle to develop in the ovary which will become the follicle deaf, if the LH and FSH are pressed the working fusion is suppressed so that de graaf follicles do not ripen, so that endometrial growth is imperfect and affects and blocks someone's ovulation. The corpus rubrum (red) is formed which will become the imperfect corpus luteum (yellow). The corpus luteum produces the hormone progesterone which will affect the endometrium which has a proliferation which will cause the glands to curl and secretion irregularly (Sukarni, 2013). In the research conducted by Setyaningrum (2008), during menstruation the respondents experienced menstrual shortening as many as 25 people and until no menstruation.

In the use of injectable contraception the combination of the ingredients is estrogen which can regulate menstruation to be regular. Ovarian hormones to produce estrogen and progesterone which will ripen the egg so that menstruation occurs which releases the uterine wall (endometrium) accompanied by bleeding that occurs every month (Ellya, 2010). The reduced amount of blood coming out on hormonal contraceptive use will affect the duration of menstruation which is affected and changed (Baziad. A, 2008). In combined normal and abnormal injection contraceptive use, this is caused by the presence of combined injectable contraceptives, namely the hormone estrogen and progesterone. Combined hormonal injection contraception works through inhibition of feedback on the hypothalamus to suppress GnRH and plasma gonadotropin secretion, thereby blocking ovulation by suppressing FSH secretion so that it suppresses estrogen release which causes non-optimal follicle maturation and progesterone content which can suppress LH work to inhibit oocyte release secondary to the follicle which will inhibit one's ovulation phase. This event will cause irregularity in one's menstrual cycle. 
A normal and regular menstrual cycle is characterized by ovulation. Then in the post ovulation period (secretion) the maturation of follicles that are not optimal will become the corpus luteum. The corpus luteum secretes the hormone progesterone and the hormone estrogen that is not optimal. At the combined use of endometrial hormonal injections injections will be atrophy which will interfere with implantation, causing endometrium to stop the production of estrogen and progesterone hormones. This condition will cause menstruation which irregularly expends blood during menstruation is not perfect and irregular menstrual periods (Purwoastuti et al. , 2015).

\subsection{Amount of Menstrual Blood in Progestin Injections and Combination Users}

The results of this study are based on the amount of menstrual blood progestin injection contraceptive categorized as abnormal $\geq 30-80 \mathrm{ml}$ per cycle, whereas in combination injection contraception users it is categorized as abnormal $\geq 30-80 \mathrm{ml}$ per cycle of 25 people (65.8\%). Accepters who use contraception for 3 months the amount of menstrual blood can be a little or a lot this is a side effect on the use of contraception (Mulyani, 2013). Menstrual blood is arterial blood, with $25 \%$ of blood coming from a vein. This blood contains residual tissue, prostaglandin, and fibrinolysin to release clots, so that normal blood menstrual blood does not experience clots unless in excessive amounts, the amount of blood coming out can be affected by several factors, including endometrial thickness, treatment, diseases that accompany the use of contraception (Ganong, 2012).

When the corpus luteum degenerates due to the absence of fertilization and implantation of the released ovum during the previous cycle, the levels of estrogen and progesterone in the fall are sharp. Because the final effects of progesterone and estrogen are preparing the endometrium for implantation and fertilized by sperm, there is a decrease in the hormones in the ovary which free prostaglandins which cause vasoconstriction of blood vessels in the endometrim. So that $\mathrm{O} 2$ distribution decreases causing endometrial death and damage to blood vessels then rinsing the endometrium into the uterine lumen. The uterine prostaglandin is a mild rhythmic contraction in the meometrium of the uterus. These contractions help to menstruate blood (Sherwood, 2014).

In the use of hormonal progestin injection contraception there is a mechanism of action by suppressing the ovulation phase of a person, the ovulation phase is good depending on the level of estrogen in the circulation. The mechanism of action is to suppress the feedback work of hypothalamic gonadotropin releasing factors. Then it will prevent pituitary secretion by inhibiting the surge of luteinizing hormone (LH) with the main 
task of blocking the ovulation phase (egg maturation). Normally the LH surge is an important indicator in the occurrence of ovulation which causes the primary follicle to develop in the ovary which will become the follicle deaf, if the LH and FSH are pressed the working fusion is suppressed so that de graaf follicles do not ripen, so that endometrial growth is imperfect and affects and blocks someone's ovulation. The corpus rubrum (red) is formed which will become the imperfect corpus luteum (yellow). The corpus luteum produces the hormone progesterone which will affect the endometrium which has a proliferation which will cause the glands to curl and secretion irregularly causing the blood to come out not optimal (Sukarni, 2013).

Whereas in combination injection use of normal contraception is relatively normal and not normal, this is caused by the presence of combined contraceptive injections, namely the hormone estrogen and progesterone. Combined hormonal injection contraception works through inhibition of feedback on the hypothalamus to suppress $\mathrm{GnRH}$ and plasma gonadotropin secretion, thereby blocking ovulation by suppressing FSH secretion so that it suppresses estrogen release which causes non-optimal follicle maturation and progesterone content which can suppress LH work to inhibit oocyte release secondary to the follicle which will inhibit one's ovulation phase. This event will cause irregularity in one's menstrual cycle. A normal and regular menstrual cycle is characterized by ovulation. Then in the post ovulation period (secretion) the maturation of follicles that are not optimal will become the corpus luteum. The corpus luteum secretes the hormone progesterone and the hormone estrogen that is not optimal. At the combined use of endometrial hormonal injection will be atrophy which will interfere with implantation, causing endometrium to stop the production of estrogen and progesterone hormones. This condition will cause menstruation which irregularly expends blood during imperfect menstruation and irregular menstrual periods (Purwoastuti et al, 2015).

\subsection{Menstrual Disorders of Progestin Injections and Combination Contraception}

In this study, the majority of those who experienced menstrual disorders amenorrhoea were found in both progestin and combination injectable contraceptive users. In progestin injection contraception users there were 20 people $(52.6 \%)$ and combined injections of 13 people (34.2\%). There are a number of different menstrual disorders from the menstrual cycle, length of menstruation and the amount of menstrual blood and whether there are ovulation problems or medical conditions (Begum.M, 2016). 
According to Manuaba. S. etAl (2009), menstrual disorders or menstruation is a combination of genetalia health and complex hormonal stimuli that originate from the hypothalamic, hypophysis and ovarian axis. Therefore, menstrual disorders can occur from abnormalities of these two factors. Based on the results of a study conducted by Manur (2007), injectable contraceptive users 1 month and 3 months experienced amenorrhea in 145 people $(75.23 \%)$.

Then the results of this study found menstrual dysmenorrhoea disorders as many as 3 people $(7.9 \%)$ in progetsin hormonal injection contraceptive users and 9 people $(23.7 \%)$ in combination hormonal injection contraceptive users. Dysmenorrhea is a subjective symptom due to increased hormone levels and contractions of the uterine muscles caused by prostaglandin. Before menstruation has increased and once menstruation has decreased prostaglandin levels, this can explain tend to decrease pain after the first few days of menstruation (Proverawati.A, 2009).

In this study, the duration of dysmenorrhea in the use of hormonal progestin injection contraception was 1 day (2.6\%) while in combination with 3 days of hormonal injection contraception, 3 people (7.9\%). Menstrual pain that is felt is usually one or two days before menstruation comes and at the first day the nature of the pain starts from mild to severe which lasts for 12 to 72 hours the longest (Putra, 2015).

\section{Conclusions}

In progestin injection contraceptive users and combinations there are abnormal menstrual patterns. So that the practice of maternity nursing can consider the provision of appropriate contraceptives for mothers who want to place pregnancies using injectable contraceptives that have side effects of use, namely the occurrence of irregular menstrual patterns so that $\mathrm{KB}$ counselors provide counseling or consultation in advance to notify what is the working mechanism of 1 month and 3 months injection contraception which results in one of the regular menstrual patterns becoming irregular.

\section{REFERENCES}

[1] Ellya, (2010). Buku Pelayanan Kebidanan Keluarga Berencana. Jakarta:EGC.

[2] Bobak, Lowdermilk, Jersen. (2004). Buku Ajar Keperawatan Maternitas/Maternity Nursing (Edisi 4), Alih Bahasa MariaAWijayati,Peter I.Anugerah,Jakarta:EGC. 
[3] Baziad, Ali. (2008). Kontrasepsi Hormonal. Jakarta: P.T Bina Pustaka Sarwono Prawirohardjo.

[4] Mulyani, Siti. N. (2013). Keluarga Berencana Dan Alat Kontrasepsi. Yogyakarta: Penerbit Nuha Medika.

[5] Monawa et Al (2016), Menstrual Disorder: CausesAnd Natural Remedies. JournalOf Pharmaceutical,Chemical And Biological Scences.

[6] Melani.Nikenet Al (2010). Pelayanan Keluarga Berencana, Yogyakarta: Fitrayama.

[7] Wirakusumah,F.(2010). Obstetric Fisiologi Imu Kesehatan Reproduksi Edisi2. Jakarta: EGC.

[8] Setyanigrum, C.A., (2008). Hubungan Lama Pemakaian Depo Medroksiprogesteron Asetat Dengan Gangguan Menstruasi Di Perumahan Petragriya Indah Purwodadi. Berita Ilmu Keperawatan ISSN 1979-2697, Vol 1. No 4. Desember 2008, 151-156.

[9] Sherwood, L. (2014). Fisiologi Manusia Dari Sel Ke Sistem Edisi 8. Jakarta: EGC.

[10] Munayarokh.et. Al.(2014). Hubungan Lama Pemakaian Kontrasepsi Suntik Dmpa Dengan Gangguan Menstruasi Di Bpm Mariyah Nurlaili, Rambe Anak Mungkid. Jurnal Kebidanan Vol. 3 No. 6 April 2014.

[11] Manuaba, S. D., et Al. (2009). Buku Ajar Ginekolgi Untuk Mahasiswa Kebidanan. Jakarta: EGC

[12] Kemenkes.RI. (2017) Profil Kesehatan Indonesia 2017. From: http://www.kemkes.go.id.

[13] Kemenkes.RI. (2014).Profil kesehatan Indonesia 2013.Jakarta. Web site: http://www.kemkes.go.id.

[14] IFPA (2008). Contraception Fact Sheet injectable contraception. SEPTEMBER 2008. Content Developed By The IFPA With Some Text Provided By Fpa Uk.http :// www.ifpa.ie

[15] Pinem.Saroha. (2009: 255). Kesehatan Reproduksi Dan Kontrasepsi.Jakarta: Trans Info Media

[16] Putra,F. (2015). Mengenal dan Memahami Bahaya Torch Bagi Wanita Hamil dan Janin. Yogyakarta: Katahati.

[17] Rejeki,Sri.etAl.(2014). Karakteristik, Status Gizi Dan Praktik Menyusui Dengan Pola Menstruasi Akseptor Kontrasepsi Suntik Di Desa Dombo Kecamatan Sayung Demak. Fakultas Keperawatan dan Kesehatan Universitas Muhammadiyah Semarang Praktisi Kesehatan.

[18] Kusmiran.E. (2011) Kesehatan Reproduksi Remaja dan Wanita, Jakarta: Salemba Medika.

[19] Purwoastuti,E., et Al. (2015). Panduan Materi Kesehatan Reproduksi Dan Keluarga Berencana. Yogyakarta: PT. Pustaka Baru.

[20] Proverawati. (2009). Menarche Menstruasi Pertama PenuhMakna.Yogyakarta:Nuha Medika. 
[21] Sukarni. (2013). Kehamilan, Persalinan, Masa Nifas. Yogyakarta: Nuha Medika.

[22] Hardisman. (2014). Gawat Darurat Medis Praktis. Yogyakarta: Gosyen Publishing. 